\title{
Motivasi dan Persepsi Penyandang Disabilitas pada Pelatihan Servis Kursi Roda dan Modifikasi Motor Roda Tiga di Desa Mlese Kecamatan Gantiwarno Kabupaten Klaten
}

\author{
Yeniar Elka Pramesiana*1, Noor Syahidah Mutiara Dzikra², Muhammad Habil \\ Azhar Hendawan ${ }^{3}$, Sadam Ridho Aditya Pratama ${ }^{4}$, Widya Nur Aisa5, \\ Siti Azizah Susilawati6
}

\begin{abstract}
1,2,3,4,5,6Fakultas Keguruan dan Ilmu Pendidikan, Universitas Muhammadiyah Surakarta, Indonesia
*e-mail: a220180039@student.ums.ac.id ${ }^{1}$, mutiaradzikra1011@gmail.com $^{2}$, habilazhar0@gmail.com ${ }^{3}$, sridho.121@gmail.com ${ }^{4}$, aisa.widyanur@gmail.com ${ }^{5}$, azizah.susilawati@ums.ac.id 6
\end{abstract}

\begin{abstract}
Abstrak
Tragedi gempa bumi yang terjadi pada tahun 2006 di Kabupaten Klaten khususnya Kecamatan Gantiwarno masih berdampak bagi kehidupan masyarakat setempat, salah satunya terhadap para penyandang disabilitas. Berdasarkan data yang tercatat, terdapat 366 penderita cacat yang berada di Kecamatan Gantiwarno ini, yang mana sebagian dari jumlah tersebut merupakan penyandang disabilitas yang merupakan korban gempa bumi pada tahun 2006. Keberhasilan yang didapat dalam memajukan komunitas badan usaha akan berpengaruh ke beberapa faktor seperti, semangat dan mental yang kuat serta peran penting yaitu keterampilan dan keahlian yang dimiliki. Kegiatan ini bertujuan untuk mengetahui motivasi dan persepsi penyandang disabilitas pada pelatihan servis kursi roda dan modifikasi motor roda tiga bagi penyandang disabilitas. Penelitian ini menggunakan metode deskriptif kualitatif dengan melakukan observasi, wawancara, dokumentasi kepada kepala desa, ketua Paguyuban Penyandang Disabilitas Klaten (PPDK), dan peserta sejumlah 30 orang penyandang disabilitas. Teknik analisis data pada penelitian ini meliputi reduksi data, penyajian data, dan penarikan kesimpulan. Kesimpulan dari penelitian ini antara lain yaitu motivasi mengikuti pelatihan servis kursi roda dan servis modifikasi motor roda tiga menunjukkan hasil perhitungan sebesar 4,73 dan terletak pada rentang skala 4,20-5,00. Hal tersebut menunjukkan bahwa pada variable motivasi mengikuti pelatihan ini tergolong pada kategori yang sangat tinggi. Rata-rata skor responden pada variable persepsi mengikuti pelatihan servis kursi roda dan servis modifikasi motor roda tiga menunjukkan hasil perhitungan sebesar 4,67 dan terletak pada rentang skala 4,20-5,00. Hal tersebut menunjukkan bahwa pada variabel persepsi mengikuti pelatihan ini tergolong pada kategori yang sangat tinggi. Jadi, motivasi dan persepsi penyandang disabilitas pada pelatihan servis kursi roda dan modifikasi motor roda tiga bagi penyandang disabilitas dapat disimpilkan termasuk kedalam kategori sangat tinggi.
\end{abstract}

Kata kunci: Motivasi dan Persepsi, Pelatihan, Penyandang Disabilitas

\begin{abstract}
The tragedy of the earthquake that occurred in 2006 in Klaten Regency, especially in the Subdistrict ofgantiwarno, still has an impact on the lives of local people, one of which is people with disabilities. Based on recorded data, there are 366 people with disabilities in this Subdistrict ofgantiwarno, of which some of them are persons with disabilities who were victims of the 2006 earthquake. and mental strength and an important role, namely the skills and expertise possessed. This activity aims to determine the motivation and perception of persons with disabilities in wheelchair service training and modification of three-wheeled motorbikes for persons with disabilities. This study used a qualitative descriptive method by conducting observations, interviews, documentation to the village head, the head of the Klaten People with Disabilities Association (PPDK), and 30 participants with disabilities. Data analysis techniques in this study include data reduction, data presentation, and drawing conclusions. The conclusion of this study, among others, is that the motivation to take part in wheelchair service training and modification services for three-wheel motorbike modifications shows the calculation results of 4.73 and lies on a scale range of 4.20-5.00. This shows that the motivation variable for participating in this training belongs to a very high category. The average score of respondents on the perception variable following the wheelchair service training and modification service for three-wheel motor modifications shows the calculation results of 4.67 and lies in the range of the scale of 4.20-5.00. This shows that the perception variable following this training belongs to a very high category. So, the motivation and perception of persons with disabilities in wheelchair service training and modification of three-wheeled motorbikes for persons with disabilities can be summarized as being in the very high category.
\end{abstract}


Keywords: Motivation and Perception, Persons with Disabilitie, Training

\section{PENDAHULUAN}

Indonesia merupakan sebuah negara yang memiliki sumber daya alam dan sumber daya manusia yang melimpah. Disamping melimpahnya seumberdaya manusia dan sumberdaya alam yang ada, sayangnya kita masih kurang dapat memanfaatkan sumber daya yang ada di dalamnya, termasuk sumber daya manusia. Sumber daya manusia sendiri merupakan inti yang sangat berperan aktif dalam mengembakan suatu organisasi atau negara (Bukit et al., 2017). Pengembangan sumber daya manusia juga memerlukan rencana dan strategi yang konsisten atau mutlak sebagai penunjang kebutuhan yang berkelanjutan, maka dari itu suatu negara memerlukan sumber daya manusia yang kompeten serta berkualitas untuk memajukan negara maupun organisasi sebagai upaya dalam peningkatan kemampuan diri (Aprizal, 2019).

Dalam pengembangan sumber daya yang ada, peranan dari sebuah perguruan tinggi baik mahasiswa maupun dosen sangatlah penting sebagai kerangka untuk pengembangan kemampuan individu dalam masyarakat, hal ini bisa didapatkan melalui kegiatan-kegiatan dalam bentuk pengabdian mahasiswa kepada masyarakat (Hadiyanti, 2008). Adapun beberapa cara untuk mengembangkan sumber daya manusia di lingkup masyarakat yaitu melalui sosialisasi dan pelatiahan yang memperioritaskan komunitas badan usaha yang ada di dalam wilayah tertentu. Dalam pengembangan komunitas badan usaha, tidak hanya perguruan tinggi namun pihak pemerintah pun ikut andil dalam pengembangan kemampuan yang dimiliki oleh sekelompok komunitas badan usaha, agar anggota komunitas badan usaha dapat memiliki kemampuan lebih untuk memajukan daya saingnya (Rosmadi, 2021).

Pengembangan kreativitas dapat dilakukan dengan berbagai cara, salah satu cara dalam mengembangkan suatu ide yang sudah didapat yaitu dengan cara menekankan pada salah satu indikator pengkontribusiannya, tidak hanya itu dukungan lainnya seperti keunggulan yang didapat, ketekunan dalam mengerjakan suatu pekerjaan, pemikiran yang terbuka, mentoleransi setiap kesempatan yang ada, mandiri, serta percaya diri (Dewi et al., 2019) sangat membantu dalam pengembangan diri. Sehingga nantinya dalam pencapaian yang didapat akan menguntungkan pihak komunitas badan usaha, sehingga akan terus berkontribusi mempertahankan usahanya dan pada akhirnya tujuan pengembangan usaha dapat terwujud. Adapula kemungkinan faktor yang dapat memotivasi pihak komunitas badan usaha untuk mempertahkan usahanya antara lain yaitu: (1) pengalaman yang didapat pada tahun dibentuknya komunitas, (2) Latar belakang budaya pada lingkungan tersebut, (3) peniruan tingkah laku, (4) harapan serta dukungan dari pihak keluarga maupun tempat terdekat (Nasution (1986: 85, n.d.).

Kabupaten Klaten merupakan salah satu bagian kabupaten yang berada di Jawa Tengah. Menurut Rencana Pembangunan Jangka Menengah Daerah (RPJMD) Kabupaten Klaten menyatakan bahwa kawasan Kabupaten yang meliputi Kecamatan Prambanan, Kecamatan Gantiwarno, Kecamatan Jogonalan, Kecamatan Wedi dan Kecamatan Bayat berada pada jalur patahan aktif dengan tingkat risiko paling tinggi. Kemudian berdasarkan data Badan Penanggulangan Bencana Daerah Klaten, Kecamatan Gantiwarna merupakan Kecamatan yang memiliki total korban baik meninggal ataupun luka-luka dengan jumlah terbanyak diantara Kecamatan lainnya.

Tragedi gempa bumi yang terjadi pada tahun 2006 di Kabupaten Klaten khususnya Kecamatan Gantiwarno masih berdampak bagi kehidupan masyarakat setempat, salah satunya terhadap para penyandang disabilitas/penderita cacat. Berdasarkan data yang tercatat, terdapat 366 penderita cacat yang berada di Kecamatan Gantiwarno ini, yang mana sebagian dari jumlah tersebut merupakan penyandang disabilitas yang merupakan korban gempa bumi pada tahun 2006. Namun keterbatasan tersebut tidak menjadi halangan untuk bertindak kreatif bagi kehidupan, salah satu tokoh disabilitas yaitu Bapak Partoyo telah mendirikan suatu paguyuban/komunitas disabilitas di Desa Mlese yang dinamakan dengan Komunitas Disabilitas "Sejahtera". Komunitas ini sudah berdiri sejak tahun 2017 yang diawali dengan usaha bengkel 
modifikasi pembuatan kendaraan bermodifikasi motor roda tiga khusus penyandang disabilitas. Walau sudah sekitar 4 tahun, komunitas "Sejahtera" masih berada pada aktivitas yang pasif, produksi kendaraan bermotor modifikasi roda tiga khusus disabilitas dan servis kursi roda ini mengalami penurunan. Selain itu tidak terfasilitasi dengan baiknya komunitas ini yang semakin membuat komunitas ini sulit dalam berproduksi.

Keberhasilan yang didapat dalam memajukan komunitas badan usaha akan berpengaruh ke beberapa faktor seperti, semangat dan mental yang kuat serta peran penting yaitu keterampilan dan keahlian yang dimiliki. Salah satu hambatan yang sering dialami dalam pengembangan komunitas badan usaha yaitu kurangnya pengetahuan tentang menciptakan motivasi sebagai penguat semangat dan mental serta rendahnya presepsi dalam masyarat tentang komunitas badan usaha (Hamid \& Si, 2018). Tujuan dalam memberikan motivasi bagi pelaku komunitas badan usaha sendiri berarti memberikan peluang untuk mengambangkan kompetensi diri sehingga dapat menghasilkan dorongan yang semaksimal mungkin dalam mengembangkan usahanya (Stie, 2021), adapula motivasi yang biasanya diberikan berupa kesejahteraan yang akan di dapat oleh pelaku komunitas badan usaha, serta dorongan mental yang nantinya bertujuan merubah presepsi (Johan et al., 2021).

Alat bantu gerak merupakan hal yang penting bagi penyandang disabilitas, misalnya kursi roda dan motor roda tiga. Apabila kursi roda maupun modifikasi motor roda tiga penyandng disabilitas mengalami kerusakan, maka hal tersebut dapat menyulitkan mereka dalam beraktifitas. Salah satu upaya untuk mengetahui motivasi dan persepsi penyandang disabilitas mengenai hal tersebut yaitu dengan diadakannya pelatihan. Oleh karena itu, kegiatan ini bertujuan untuk mengetahui motivasi dan persepsi penyandang disabilitas pada pelatihan servis kursi roda dan modifikasi motor roda tiga di Desa Mlese Kecamatan Gantiwarno Kabupaten Klaten.

\section{METODE}

Kegiatan pengabdian masyarakat ini dilaksankan melalui tiga tahapan yaitu perencanaan, pelaksanaan, dan evaluasi. Kegiatan yang dilaksanakan pada tanggal 19 September 2021 di Balai Desa Mlese Kecamatan Gantiwarno Kabupaten Klaten ini secara khusus bertujuan untuk membantu penyandang disabilitas untuk memperbaiki alat mobilitasnya agar tidak harus ke bengkel pada saat kursi roda atau motor roda tiganya mengalami kerusakan. Pada kegiatan pengabdian masyarakat ini menggunakan metode deskriptif kualitatif dengan sumber data primer, yaitu dengan melakukan observasi, dokumentasi, wawancara (kepada kepala Desa Mlese, ketua Paguyuban Penyandang Disabilitas Klaten), dan kuesioner (kepada peserta yaitu 30 orang penyandang disabilitas).

Indikator yang digunakan untuk mengukur motivasi antara lain, yaitu dorongan dan semangat. Sedangkan indikator yang yang digunakan untuk mengukur persepsi antara lain, yaitu kinerja, fitur atau ciri-ciri tambahan, reliabilitas, kesesuaian dengan spesifikasi, daya tahan, serviceability, estetika, dan kualitas yang dipersepsikan. Instrument yang digunakan merujuk pada penelitian Fransiska Nunuk Puji Raharjanti (2016). Teknik analisis data pada penelitian ini meliputi reduksi data, penyajian data, dan penarikan kesimpulan.

\section{HASIL DAN PEMBAHASAN}

\subsection{Perencanaan Pelatihan Servis Kursi Roda dan Modifikasi Motor Roda Tiga bagi Penyandang Disabilitas}

Kegiatan perencanaan untuk motivasi dan persepsi penyandang disabilitas ini dilaksanakan melalui pelatihan servis kursi roda dan motor roda tiga. Penyandang disabilitas di Desa Mlese Kecamatan Gantiwarno Kabupaten Klaten ini sudah dibekali dengan pelatihanpelatihan yang diselenggarakan oleh BPBD. Kegiatan ini diharapkan dapat mengetahui motivasi dan persepsi mengenai pelatihan servis kursi roda dan motor roda tiga. Pada kegiatan awal akan 
dimulai dengan memberikan pengenalan mengenai alat-alat yang digunakan untuk servis kemudian dijelaskan sedikit mengenai pentingnya servis. Lalu dilaksanakan pelatihan dengan praktik langsung dengan menggunakan alat-alat yang disediakan oleh panitia. Luaran yang diharapkan dalam pelatihan ini adalah dapat membantu penyandang disabilitas untuk memperbaiki alat mobilitasnya agar tidak harus ke bengkel pada saat kursi roda atau motor roda tiganya mengalami kerusakan.

\subsection{Pelaksanaan Pelatihan Servis Kursi Roda dan Modifikasi Motor Roda Tiga bagi Penyandang Disabilitas}

Pelaksanaan pelatihan dilaksanakan pada tanggal 19 September 2021 pada pukul 08.0012.00 WIB. Pelatihan tersebut dilaksanakan dengan dua kegiatan yaitu pelatihan servis kursi roda dan modifikasi motor roda tiga dalam waktu yang bersamaan. Pelatihan servis kursi roda dilakukan di Joglo Desa Mlese, sedangkan pelatihan servis modifikasi motor roda tiga dilaksanakan di Aula Balai Desa Mlese. Kegiatan tersebut diikuti oleh 15 orang pada masingmasing pelatihan.

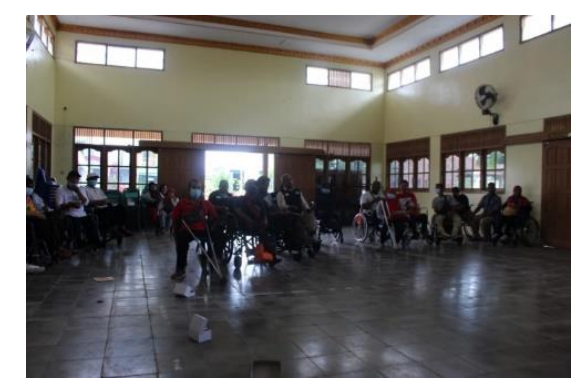

(a)

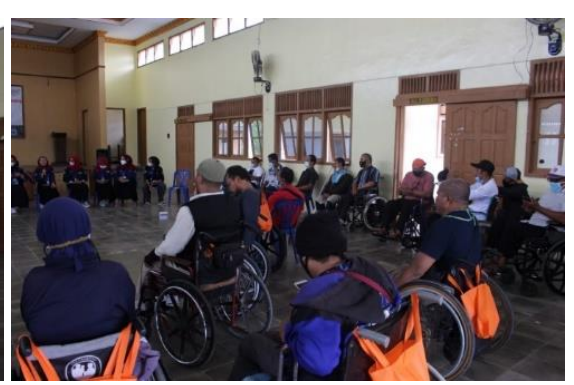

(b)

Gambar 1. Pembukaan pelatihan servis kursi roda dan modifikasi motor roda tiga di Aula Balai Desa Mlese (a) peserta (b) sambutan

Pelatihan tersebut diawali dengan sambutan dari ketua pelaksana, dosen pendamping, dan perwakilan peserta. Acara dilanjutkan dengan perkenalan dan penyampaian materi oleh narasumber yaitu dari PPDK (Paguyuban Penyandang Disabilitas Klaten), dimana pemilihan narasumber ini adalah orang yang berkompeten didalam bidangnya. Setelah materi disampaikan secara singkat, kemudian peserta melakukan praktik yang dipandu oleh narasumber secara langsung. Berikut ini merupakan gambar-gambar pelaksanaan pelatihan.

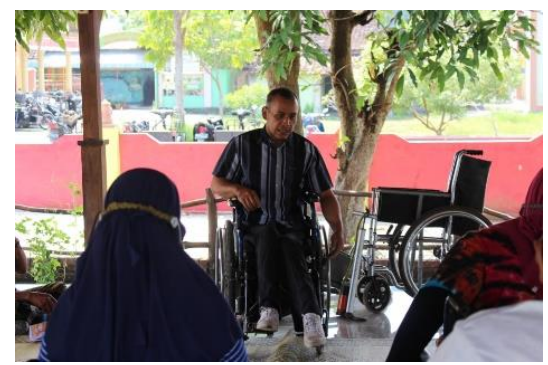

Gambar 2. Penyampaian materi oleh narasumber

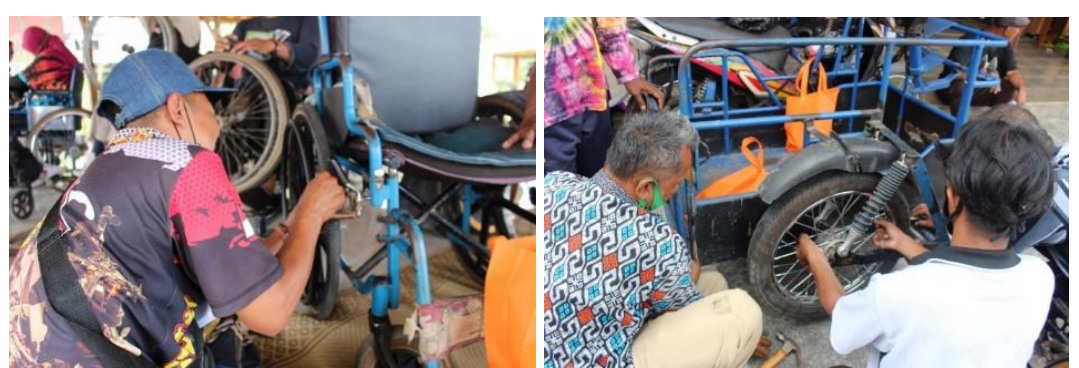

Gambar 3. Praktik pelatihan (a) servis kursi roda (b) servis modifikasi motor roda tiga 
Selama kegiatan tersebut peserta sangat antusias dalam mengikuti kegiatan pelatihan yang dijelaskan oleh narasumber. Hal tersebut dapat dilihat dari gambar-gambar peserta pada saat diberikan pelatihan, mereka langsung mempraktikkan langkah-langkah yang didemonstrasikan oleh narasumber. Arahan yang disampaikan oleh narasumber menggunakan bahasa yang mudah dipahami. Peserta pelatihan terlihat antusias pada sesi praktik bersama ini. Peserta menanyakan masalah-masalah yang pernah mereka alami di kehidupan sehari-hari. Kemudian narasumber menjelaskan langkah-langkah yang harus peserta lakukan ketika menghadapi masalah-masalah tersebut.

Setelah pelaksanaan pelatihan, kemudian kami melakukan penjumlahan atas jawaban responden untuk setiap item pernyataan dalam kuesioner untuk mengetahui rumusan masalah dari penelitian ini. Sebelumnya ditentukan terlebih dahulu kelas interval untuk menentukan jawaban rata-rata responden. Adapun perhitungan untuk menentukan kelas interval yaitu sebagai berikut (Budiasih, 2012):

$$
\begin{aligned}
\text { Kelas interval } & =\frac{\text { nilai maksimum-nilai minimum }}{\text { kelas interval }} \\
& =\frac{5-1}{5} \\
& =0,80
\end{aligned}
$$

Adapun skala data tersebut adalah sebagai berikut:

Tabel 1. Hasil interpretasi respon dari responden

\begin{tabular}{ccc}
\hline Skala data & Kelas & Kategori \\
\hline 1 & $1,00-1,79$ & Sangat rendah \\
2 & $1,80-2,59$ & Rendah \\
3 & $2,60-3,39$ & Cukup \\
4 & $3,40-4,19$ & Tinggi \\
5 & $4,20-5,00$ & Sangat tinggi \\
\hline
\end{tabular}

\subsubsection{Analisis deskriptif variable motivasi mengikuti pelatihan servis kursi roda dan servis modifikasi motor roda tiga}

\begin{tabular}{|c|c|c|c|}
\hline Item & Indikator & $\begin{array}{l}\text { Rata-rata } \\
\text { per item }\end{array}$ & $\begin{array}{c}\text { Total skor } \\
\text { rata-rata }\end{array}$ \\
\hline 1 & $\begin{array}{l}\text { Anda terdorong mengikuti pelatihan untuk merubah } \\
\text { hidup Anda menjadi lebih baik. }\end{array}$ & 4,67 & \multirow{4}{*}{4,73} \\
\hline 2 & $\begin{array}{l}\text { Anda terdorong mengikuti program pelatihan untuk } \\
\text { meningkatkan keterampilan yang Anda miliki. }\end{array}$ & 4,72 & \\
\hline 3 & $\begin{array}{l}\text { Anda bersemangat mengikuti program pelatihan yang } \\
\text { diajarkan. }\end{array}$ & 4,84 & \\
\hline 4 & $\begin{array}{l}\text { Anda mengikuti pelatihan ini untuk memenuhi kebutuhan } \\
\text { Anda di masa mendatang. }\end{array}$ & 4,70 & \\
\hline
\end{tabular}

Tabel 2. Deskripsi variable motivasi mengikuti pelatihan servis kursi roda dan servis modifikasi motor roda tiga

Sumber: Data Primer yang Diolah, 2021

Berdasarkan Tabel 2, rata-rata skor responden pada variable motivasi mengikuti pelatihan servis kursi roda dan servis modifikasi motor roda tiga menunjukkan hasil perhitungan sebesar 4,73 dan terletak pada rentang skala 4,20-5,00. Hal tersebut menunjukkan bahwa pada variable motivasi mengikuti pelatihan ini tergolong pada kategori yang sangat tinggi. Dari tabel tersebut, dapat diketahui bahwa item pernyataan pada variable motivasi mengikuti pelatihan servis kursi roda dan servis modifikasi motor roda tiga yang memiliki skor paling rendah adalah "Anda terdorong mengikuti pelatihan untuk merubah hidup Anda menjadi 
lebih baik" dengan skor rata-rata paling rendah 4,67 dan terletak pada rentang skala 4,20-5,00 yang berarti berada pada kategori sangat tinggi. Sedangkan skor pernyataan yang paling tinggi terdapat pada item pernyataan "Anda bersemangat mengikuti program pelatihan yang diajarkan" dengan skor rata-rata sebesar 4,84 dan terletak pada rentang skala 4,20-5,00 yang berarti termasuk dalam kategori sangat tinggi.

\subsubsection{Analisis deskriptif variable persepsi mengikuti pelatihan servis kursi roda dan servis modifikasi motor roda tiga}

Tabel 3. Deskripsi variable persepsi mengikuti pelatihan servis kursi roda dan servis modifikasi motor roda tiga

\begin{tabular}{clcc}
\hline Item & \multicolumn{1}{c}{ Indikator } & $\begin{array}{c}\text { Rata-rata } \\
\text { per item }\end{array}$ & $\begin{array}{c}\text { Total skor } \\
\text { rata-rata }\end{array}$ \\
\hline 1 & $\begin{array}{l}\text { Program pelatihan yang Anda ikuti sudah disesuaikan } \\
\text { dengan kebutuhan dan keterbatasan Anda. }\end{array}$ & 4,50 & \\
2 & $\begin{array}{l}\text { Pelatihan sudah didukung dengan kelengkapan alat-alat } \\
\text { yang mempermudah dalam pelatihan Anda. }\end{array}$ & 4,33 & \\
3 & $\begin{array}{l}\text { Alat-alat dalam sarana pelatihan Anda berada dalam kondisi } \\
\text { yang baik. }\end{array}$ & 4,20 & \\
4 & $\begin{array}{l}\text { Pelatih yang memberi bimbingan kepada Anda memiliki } \\
\text { keahlian dibidangnya. }\end{array}$ & 4,95 & \\
5 & $\begin{array}{l}\text { Program pelatihan yang disediakan mampu menjadi bekal di } \\
\text { masa depan Anda. }\end{array}$ & 4,67 & 4,67 \\
6 & $\begin{array}{l}\text { Pelatih bersedia memberi perhatian khusus apabila Anda } \\
\text { mengalami kesulitan dalam proses pelatihan. }\end{array}$ & 4,80 & \\
7 & $\begin{array}{l}\text { Anda mudah memahami teori-teori pada program pelatihan } \\
\text { yang sudah diberikan. }\end{array}$ & 4,84 & \\
8 & $\begin{array}{l}\text { Anda mudah mengikuti setiap langkah-langkah pada } \\
\text { program pelatihan yang Anda ikuti. }\end{array}$ & 4,84 \\
9 & $\begin{array}{l}\text { Pelatihan dalam praktik langsung lebih mengembangkan } \\
\text { ketrampilan Anda. }\end{array}$ & 4,67 & \\
10 & $\begin{array}{l}\text { Program pelatihan yang diberikan menarik perhatian Anda. } \\
\text { Anda merasa program pelatihan yang diberikan sudah } \\
\text { bervariasi. }\end{array}$ & 4,80 & 4,67 \\
12 & $\begin{array}{l}\text { Anda merasa pelatihan yang diberikan sudah mampu } \\
\text { meningkatkan kualitas diri Anda. }\end{array}$ & 4,80 & \\
13 & $\begin{array}{l}\text { Anda merasa pelatihan yang Anda ikuti mampu membuat } \\
\text { Anda berkompetisi di masyarakat. }\end{array}$ & 4,67 & \\
\hline
\end{tabular}

Sumber: Data Primer yang Diolah, 2021

Berdasarkan Tabel 3, rata-rata skor responden pada variable persepsi mengikuti pelatihan servis kursi roda dan servis modifikasi motor roda tiga menunjukkan hasil perhitungan sebesar 4,67 dan terletak pada rentang skala 4,20-5,00. Hal tersebut menunjukkan bahwa pada variable persepsi mengikuti pelatihan ini tergolong pada kategori yang sangat tinggi. Dari tabel tersebut, dapat diketahui bahwa item pernyataan pada variable motivasi mengikuti pelatihan servis kursi roda dan servis modifikasi motor roda tiga yang memiliki skor paling rendah adalah "pelatihan sudah didukung dengan kelengkapan alat-alat yang mempermudah dalam pelatihan Anda" dengan skor rata-rata paling rendah 4,33 dan terletak pada rentang skala 4,20-5,00 yang berarti berada pada kategori sangat tinggi. Sedangkan skor pernyataan yang paling tinggi terdapat pada item pernyataan "pelatih yang memberi bimbingan kepada Anda memiliki keahlian dibidangnya" dengan skor rata-rata sebesar 4,95 dan terletak pada rentang skala 4,20-5,00 yang berarti termasuk dalam kategori sangat tinggi. 


\subsection{Evaluasi Pelatihan Servis Kursi Roda dan Modifikasi Motor Roda Tiga bagi \\ Penyandang Disabilitas}

Pelatihan servis modifikasi motor dan kursi roda ini diharapkan dapat membantu mereka dalam menyelesaikan permasalahan dasar alat bantu mobilitas yang mereka gunakan. Selain itu dengan adanya pelatihan servis ini dapat memudahkan para penyandang disabilitas untuk menyelesaikan sendiri kerusakan yang terjadi pada motor modifikasi dan kursi roda yang mereka miliki tanpa harus datang ke bengkel. Hal ini yang akan memudahkan mereka dan juga dapat menghemat biaya serta waktu.

Adanya evaluasi pelatihan servis modifikasi motor dan kursi roda bagi penyandang disabilitas yang dilaksanakan pada masa pandemi COVID-19 ini tidak menjadi penghalang bagi penyandang disabilitas. Acara yang diselenggarakan berjalan dengan baik, meskipun adanya keterbatasan waktu yang seharusnya pelatihan dilaksanakan tiga hari sampai tujuh hari namun kali ini hanya setengah hari saja. Walaupun demikian, kegiatan tidak terhambat. Setidaknya dari penyandang disabilitas mengerti mengenai materi dasar servis kursi roda dan servis modifikasi motor roda tiga. Penulis mengharapkan kegiatan pelatihan ini dapat dilanjutkan oleh pihakpihak terkait.

\section{KESIMPULAN}

Hasil penelitian menunjukkan bahwa adanya pelatihan servis kursi roda dan modifikasi motor roda tiga dapat mengubah hidup penyandang disabilitas di Desa Mlese Kecamatan Gantiwarno Kabupaten Klaten menjadi lebih baik, meningkatkan semangat dalam mengikuti program pelatihan dan dapat memenuhi kebutuhan mereka di masa mendatang. Selain itu adanya pelatihan servis ini dapat menjadi bekal mereka dalam menyelesaikan permasalahan pada alat batu mobilitas yang mereka miliki. Teori-teori servis yang mereka peroleh juga dapat menjadi dasar pengetahuan dalam memperbaiki kerusakan-kerusakan kecil pada alat bantu mobiltas yang mereka gunakan. Hal ini juga bisa menghemat biaya dan waktu karena mereka dapat memperbaiki sendiri tanpa harus membawa ke bengkel.

Kesimpulan dari penelitian ini antara lain yaitu motivasi mengikuti pelatihan servis kursi roda dan servis modifikasi motor roda tiga menunjukkan hasil perhitungan sebesar 4,73 dan terletak pada rentang skala 4,20-5,00. Hal tersebut menunjukkan bahwa pada variable motivasi mengikuti pelatihan ini tergolong pada kategori yang sangat tinggi. Rata-rata skor responden pada variable persepsi mengikuti pelatihan servis kursi roda dan servis modifikasi motor roda tiga menunjukkan hasil perhitungan sebesar 4,67 dan terletak pada rentang skala 4,20-5,00. Hal tersebut menunjukkan bahwa pada variable persepsi mengikuti pelatihan ini tergolong pada kategori yang sangat tinggi. Jadi, motivasi dan persepsi penyandang disabilitas pada pelatihan servis kursi roda dan modifikasi motor roda tiga bagi penyandang disabilitas dapat disimpilkan termasuk kedalam kategori sangat tinggi.

\section{DAFTAR PUSTAKA}

Aprizal, A. (2019). Pengaruh Motivasi Dan Lingkungan Kerja Terhadap Kinerja Pegawai Pada Kantor Kecamatan Panakkukang. Bongaya Journal for Research in Management (BJRM), 2(2), 23-31. https://doi.org/10.37888/bjrm.v2i2.179

Budiasih, Yanti. (2012). Statistika Deskriptif Untuk Ekonomi \& Bisnis. Tangerang: Jelajah Nusa.

Bukit, B., Malusa, T., \& Rahmat, A. (2017). Pengembangan Sumber Daya Manusia. Teori, Dimensi Pengukuran,. file:///C:/Users/Smile/Downloads/manajemen sumber daya manusia ( PDFDrive.com ).pdf

Dewi, S. R., Andari, A., \& Masitoh, M. R. (2019). Peran Pelatihan Dan Workshop Bagi Peningkatan Motivasi, Inovasi Dan Kreativitas Pada Umkm Kerajinan Tangan Dari Manik-Manik. Kaibon Abhinaya : Jurnal Pengabdian Masyarakat, 1(2), 59. https://doi.org/10.30656/ka.v1i2.1509

Hadiyanti, P. (2008). Strategi Pemberdayaan Masyarakat Melalui Program Keterampilan 
Produktif Di Pkbm Rawasari, Jakarta Timur. Perspektif Ilmu Pendidikan, 17(IX), 90-99. https://doi.org/10.21009/pip.171.10

Hamid, I. H., \& Si, M. (2018). Manajemen pemberdayaan masyarakat (M. S. Tuty Suciaty Razak, SH. (ed.); Cetakan ke). De La Macca (Anggota IKAPI Sulsel).

Johan, M., Budiadnyana, G. N., Admiral, Asbari, M., \& Novitasari, D. (2021). Kepemimpinan Karismatik dalam Perspektif Karyawan UMKM: dari Motivasi Intrinsik hingga Tacit Knowledge Sharing. Edumaspul: Jurnal Pendidikan, 5(1), 598-613.

Nasution (1986: 85. (n.d.). upaya guru dalam membangkitkan motivasi belajar.

Raharjanti, Fransiska Nunuk Puji. (2016). Pengaruh Persepsi Atas Kualitas Pelatihan Dan Motivasi Mengikuti Pelatihan Pada Niat Berwirausaha Pada Kaum Difabel di Daerah Istimewa Yogyakarta.Yogyakarta.

Rosmadi, M. L. N. (2021). Inovasi dan Kreativitas Pelaku Usaha UMKM di Era Covid-19. Jurnal IKRA-ITH Ekonomika, 4(2), 87-94.

Stie, Y. A. I. (2021). KOPERASI DAN UMKM Disusun Oleh : Drs . Zainal Arifin , MM. 